\title{
Anti-Hairy Cell Leukemia Antibody DBA.44
}

National Cancer Institute

\section{Source}

National Cancer Institute. Anti-Hairy Cell Leukemia Antibody DBA.44. NCI Thesaurus.

Code C126899.

A mouse monoclonal antibody directed ag ainst an epitope expressed by the DEAU B-

lymphoma cell line, with potential diagnostic applications ex vivo. Anti-hairy cell leukemia antibody DBA.44 detects an antigen expressed on a subpopulation of B-lymphocytes in the mantle zone of lymphoid follicles. DBA.44 reacts with the majority of lymphocytes of hairy cell leukemia $(\mathrm{HCL})$. 